\title{
Evolution of Blood Donation Patterns in a Hospital-based Blood Centre over a Seven-year Period: Implications for Donor Recruitment and Retention
}

\author{
LM Buchner-Daley ${ }^{1}$, DC Brady-West ${ }^{1}$, DA McGrowder ${ }^{1}$, GM Gordon-Strachan ${ }^{2}$
}

\begin{abstract}
Objective: The aim of this study is to investigate the effect of a public appeal to encourage voluntary blood donation by comparing the pattern of blood donations in 2000 and 2007.

Methods: A retrospective analysis of blood donation records was conducted at the University Hospital of the West Indies (UHWI) Blood Collection Centre from April to December of 2000 and 2007. Data were analysed to identify any significant changes in donation patterns and donor profiles.

Results: The total number of blood donor records reviewed was 3194 in 2000 and 2634 in 2007 representing $69.0 \%$ and $72.3 \%$ of the total blood donations, respectively. Autologous donations accounted for $1 \%$ in 2000 and $2.2 \%$ in 2007; however, there was no corresponding change in voluntary donations (3.4\% in 2000 and 3.2\% in 2007). Despite a reduction in the number of first-time donors (1539 in 2000 and 1115 in 2007), the percentage of units discarded for the presence of a marker of transfusion transmission infection (TTI) increased, being 6.5\% in 2000 and $7.4 \%$ in 2007. Human Tlymphotropic virus (HTLV) was the most common infectious marker in 2000 (3.4\% of donors) whereas reactive Venereal Disease Research Laboratory (VDRL) predominated in 2007 (3.6\% of donors).

Conclusion: The per capita donations (0.99\% in 2000 and $0.88 \%$ in 2007) failed to meet the World Health Organization (WHO) recommendation for an adequate blood supply of 1-3\%. Despite a national effort to improve voluntary donations, the positive changes in the pattern of blood donation over a period of seven years were limited to a decrease in the proportion of first-time donors and an increase in blood donors with one to four previous donations.
\end{abstract}

Keywords: Donations, donor recruitment, retention, voluntary

\section{Evolución de los Patrones de Donación de Sangre en un Centro Hematológico Hospitalario durante un Período de Siete Años: Implicaciones para el Reclutamiento y la Retención de Donantes}

LM Buchner-Daley ${ }^{1}$, DC Brady-West ${ }^{1}$, DA McGrowder ${ }^{1}$, GM Gordon-Strachan ${ }^{2}$

\begin{abstract}
RESUMEN
Objetivo: El objetivo de este estudio es investigar el efecto de un llamado público para fomentar la donación voluntaria de sangre, comparando el patrón de las donaciones de sangre en 2000 y 2007.

Métodos: Se realizó un análisis retrospectivo de expedientes de donación de sangre en el Centro de recogida de sangre del Hospital Universitario de West Indies desde abril a diciembre de 2000 y 2007. Los datos fueron analizados para identificar cambios significativos en los patrones de donación y perfiles de donantes.

Resultados: El número total de registros de donantes de sangre revisados fue 3194 en 2000 y 2634 en 2007, lo que representa el 69,0\% y 72,3\% del total de las donaciones de sangre, respectivamente. Las donaciones autólogas representaron el 1\% en el año 2000 y el 2.2\% en 2007. Sin embargo, no hubo un cambio correspondiente con respecto a las donaciones voluntarias $(3.4 \%$ en el año 2000 y $3.2 \%$ en 2007). A pesar de la reducción en el número de donantes primerizos (1539 en 2000 y 1115 en 2007),
\end{abstract}

From: ${ }^{1}$ Department of Pathology and ${ }^{2}$ Research Centre, Dean's Office, Faculty of Medical Sciences, The University of the West Indies, Kingston 7, Jamaica, West Indies.
Correspondence: Dr LM Buchner-Daley, Department of Pathology, Faculty of Medical Sciences, The University of the West Indies, Kingston 7, Jamaica, West Indies. Fax: 876-977-4704, e-mail: loretta.buchner@ gmail.com 
aumentó el porcentaje de unidades descartadas por la presencia de un marcador de infección transmitida por transfusión, que fue de un $6.5 \%$ en 2000 y 7,4\% en 2007. El virus linfotrópico humano de células T (HTLV) fue el marcador de infecciones más común en el año 2000 (3.4\% de los donantes) mientras que las pruebas reactivas del Laboratorio de Investigación de Enfermedades Venéreas (VDRL), predominaron en 2007 (3.6\% de los donantes).

Conclusión: Las donaciones per cápita (0.99\% en el año 2000 y 0.88\% en 2007) no cumplieron con la recomendación de la Organización Mundial de la Salud (OMS) en cuanto a un adecuado suministro de sangre de 1-3\%. A pesar del esfuerzo nacional por mejorar las donaciones voluntarias, los cambios positivos en el patrón de la donación de sangre durante un período de siete años, se limitaron a una disminución en la proporción de donantes primerizos, un aumento de los donantes de sangre con una a cuatro donaciones previas.

Palabras claves: Donaciones de sangre, reclutamiento de donantes, retención, voluntario

West Indian Med J 2013; 62 (7): 633

\section{INTRODUCTION}

The continuous threat of transfusion transmissible infectious agents and the increasing advances in new surgical procedures carry serious implications for the balance between blood product safety and supply. This balance is most challenging for developing countries, and is only achievable with an adequate pool of safe blood donors and effective testing of donated blood. Published data have confirmed that the safest blood donors are repeat, voluntary non-remunerated donors from low-risk populations $(1,2)$.

Jamaica requires approximately 52000 units of blood annually to be self-sufficient based on the World Health Organization (WHO) minimum criteria of $1-3 \%$ of a country's population donating to maintain an adequate blood supply (3). The limitations of donor recruitment and retention in developing countries lead to the reliance by National Blood Transfusion Services (NBTS) on replacement donors to meet the growing demand for blood and its components.

Donor demographics in Jamaica are typical of developing countries, with predominantly first-time replacement donors, a high (30\%) rate of rejection of potential donors and significant percentage of units discarded due to seropositivity for markers of transmissible diseases (4). With this in mind, the NBTS has implemented the following strategies in order to transform the current donor pool to voluntary donation by 2015 in an effort to improve the safety and supply of blood: collaboration with corporate Jamaica, governmental and non-governmental organizations with hosting of blood drives and the continued education of their employees with regards to blood donation; education of the populace through the print and electronic media with regards to blood donation; implementation of clubs directed at blood transfusion to attract young donors and improvement in the infrastructure of blood collection centres.

The creation and maintenance of donor databases facilitates the identification of demographic factors related to repeat donation and seroprevalence, and thus informs guidelines for recruitment strategies (5).
The objective of this study was to analyse and compare the donor populations in the blood centre of a tertiary care institution over a seven-year interval, in order to assess the success of the donor recruitment strategies introduced at the outset of that period. Information obtained may be useful to identify the ideal target group for education and motivation toward the development of a voluntary blood donor database.

\section{SUBJECTS AND METHODS}

The University Hospital of the West Indies (UHWI) is a tertiary care 500-bed institution and serves as the location for the second largest blood collection centre of the NBTS. The hospital is located in close proximity to several educational and training centres.

A retrospective analysis of the blood donation records was conducted at the UHWI Blood Collection Centre during the periods April to December of 2000 and 2007. The demographics of the donor, the type of donation (voluntary, replacement or autologous) and the number of previous donations were extracted from the records. For replacement donors, the relationship of the donor to the intended recipient as well as the service to which the recipient belonged was also recorded. Routine screening tests at the NBTS are Venereal Disease Research Laboratory (VDRL) test for syphilis, hepatitis B surface antigen (HBsAg) and antibodies for hepatitis C, human immunodeficiency virus (HIV) and human T-lymphotropic virus type 1 (HTLV-1). We defined a regular, repeat blood donor as one who has given blood more than once and the interval between donations does not exceed 12 months. Data were analysed using SPSS 11.5 (SPSS Inc, Chicago, Illinois, United States of America). The statistical analysis includes absolute (n) and relative frequency (\%) distribution of the qualitative parameters. Values for continuous variables are expressed as mean \pm SEM. The significance between the groups was determined using the Chisquare test with $p<0.05$ considered to be significant. 


\section{RESULTS}

Blood collection in Jamaica was 25932 in 2000 and 23686 in 2007 . As a function of the population, this reflected $0.99 \%$ and $0.88 \%$ in 2000 and 2007, respectively. This is a significant decline $(p=0.0016)$. The number of blood donor records reviewed comprised 3194 in 2000 and 2634 in 2007, $(p=0.001)$. This represented $69.0 \%$ and $72.3 \%$ of the total blood donations in 2000 and 2007, respectively. In both years, males donated blood more commonly than females with a M:F ratio of 2.5:1 (2000) and 3.2:1 (2007). The mean age of the donor population was $32.24 \pm 0.18$ years and 33.48 \pm 0.20 years in 2000 and 2007, respectively. Donors in the $17-24$-year age group accounted for $23.0 \%$ in 2000 and $21.0 \%$ in 2007 .

Information regarding marital status and employment status was only available for blood donors in 2000; then, the donor was single and employed in $60.0 \%$ and $81.0 \%$ of the study population, respectively.

Replacement donors dominated the donor pool, accounting for $95.0 \%$ of the total in both years. Altruistic voluntary donors were in the minority with $3.4 \%$ (2000) and $3.2 \%$ (2007). Replacement donors frequently donated for surgical and obstetric/gynaecological patients $(77.0 \%$ in 2000 and $74.1 \%$ in 2007). Spouses gave overwhelmingly for obstetric and gynaecological patients with $90.9 \%$ (2000) and $88.9 \%$ (2007) of the total donors for this group. Blood donations made for patients undergoing elective surgery came from relatives $(56.5 \%)$ and non-relatives $(49.2 \%)$ in 2000 with a similar pattern in 2007 (relatives $48.8 \%$ and nonrelatives $37.9 \%$ ). Autologous donations accounted for $1.0 \%$ of all donations for surgical patients in 2000. This was doubled to $2.2 \%$ in 2007 .

Between 2000 and 2007, the number of first-time donors significantly decreased $(p=0.001)$ while those with one to four donations significantly increased $(p=0.001)$. Donors with five or more blood donations were in the minority at $8.3 \%$ and $10.7 \%$ in 2000 and 2007 , respectively (Table 1).

Table 1: The number of donations in 2000 and 2007

\begin{tabular}{lcc}
\hline $\begin{array}{l}\text { Number of prior } \\
\text { donations }\end{array}$ & $\begin{array}{c}\mathbf{2 0 0 0} \\
\mathbf{n} \mathbf{3 1 9 4} \\
\mathbf{( \% )}\end{array}$ & $\begin{array}{c}\mathbf{2 0 0 7} \\
\mathbf{n}=\mathbf{2 6 3 4} \\
\mathbf{( \% )}\end{array}$ \\
\hline 0 & 48.2 & 42.3 \\
$1-4$ & 43.3 & 47.0 \\
$5-9$ & 5.8 & 7.6 \\
$\geq 10$ & 2.5 & 3.1 \\
\hline
\end{tabular}

Significance $p<0.001$

Positivity for a marker of transfusion transmissible infection (TTI) was 6.5\% (2000) and 7.4\% (2007) among the donors (Table 2). Volunteers in 2000 were less likely to be seropositive $(3.6 \%)$ than replacement donors $(6.7 \%)$. The same trend continued in 2007 with $1.2 \%$ seropositivity for
Table 2: Serological markers of transfusion transmitted infections among donors in 2000 and 2007

\begin{tabular}{lcc}
\hline $\begin{array}{l}\text { Serological markers of } \\
\text { transfusion transmitted } \\
\text { infections }\end{array}$ & $\begin{array}{c}\mathbf{2 0 0 0} \\
\mathbf{n}=\mathbf{2 0 9}\end{array}$ & $\begin{array}{c}\mathbf{2 0 0 7} \\
\mathbf{n}=\mathbf{1 9 4}\end{array}$ \\
& $\mathbf{( \% )}$ & $\mathbf{( \% )}$ \\
\hline HTLV & 3.4 & 1.8 \\
HCV & 1.0 & 0.2 \\
HBV & 0.9 & 0.9 \\
HIV & 0.6 & 0.6 \\
VDRL & 0.4 & 3.6 \\
Other & 0.2 & 0.3 \\
\hline Total & $\mathbf{6 . 5}$ & $\mathbf{7 . 4}$
\end{tabular}

HTLV = human T-lymphotropic virus, $\mathrm{HCV}=$ hepatitis $\mathrm{C}$ virus, HBV = hepatitis $\mathrm{B}$ virus; HIV = human immunodeficiency virus, VDRL=

Venereal Disease Research Laboratory

voluntary donations and $7.8 \%$ for replacement donations. Human T-lymphotropic virus type 1 was the most common infectious marker in 2000 (3.4\% of donors) whereas VDRL reactivity predominated in 2007 (3.6\% of donors). With respect to donation history, the profile of donors with a single TTI was similar over the period studied whilst the profile of the donors having multiple markers of TTI was different (Table 3).

Table 3: Seropositivity for single and multiple infectious markers among donors in 2000 and 2007

\begin{tabular}{ccccc}
\hline & \multicolumn{2}{c}{ Single } & \multicolumn{2}{c}{ Multiple } \\
Number of prior & $\mathbf{2 0 0 0}$ & $\mathbf{2 0 0 7}$ & $\mathbf{2 0 0 0}$ & $\mathbf{2 0 0 7}$ \\
donations & $\mathbf{n = 2 0 0}$ & $\mathbf{n = 1 8 2}$ & $\mathbf{n = 8}$ & $\mathbf{n = 6}$ \\
& $(\%)$ & $(\%)$ & $(\%)$ & $(\%)$ \\
\hline 0 & 45.5 & 45.1 & 87.5 & 50.0 \\
$1-4$ & 50.5 & 46.2 & 12.5 & 50.0 \\
$5-9$ & 3.0 & 4.9 & 0 & 0 \\
$\geq 10$ & 1.0 & 3.8 & 0 & 0 \\
\hline
\end{tabular}

\section{DISCUSSION}

The number of records reviewed in 2007 compared to 2000 was $17.5 \%$ fewer. This likely reflects two factors: the study period (April-December) included the traditional end of year decline in blood donations and this would be compounded by an $8.7 \%$ overall decrease in annual blood donation between the 2000 and 2007 study periods.

The WHO recommends that $1 \%$ to $3 \%$ of a country's population donate blood to meet the needs of that country (3). The population statistics for Jamaica reveal a population of 2607633 in 2001 and 2682100 in $2007(6,7)$. As a percentage of the total population, donors accounted for $0.99 \%$ and $0.88 \%$ over the two periods of time studied which represented a significant decline $(p=0.0016)$. Blood inventory worldwide is declining with expansion of deferral criteria and falling retention rates; therefore continuous evaluation of blood donor demographic and donation characteristics is essential for maintaining an adequate supply of safe blood 
products. This can only be reliably assured by regular donations from voluntary non-remunerated donors. Many developing countries, like Jamaica, still rely heavily on relatively unsafe replacement donors. As the NBTS in Jamaica seeks to transform into a voluntary donor base and reduce its dependency on replacement donors, the analysis of donor demographics may facilitate the creation of a database for potential voluntary donors.

The profile of a typical blood donor at the UHWI Blood Collection centre remained unaltered for the period studied: ie male in the $4^{\text {th }}$ decade of life. Previous research has revealed a higher rate of deferral in females, primarily because of anaemia (4). Education on good nutrition with early identification and treatment of anaemia may be initiated at the blood centre in order to retain a potential donor after the problem has been resolved. The decline in the number of donors aged 17-24 years may reflect the inadequate implementation of blood donation strategies by the NBTS to motivate the students in secondary and tertiary institutions to become regular voluntary donors. This group of donors represents an untapped source for blood donation as these are healthy individuals. Implementation of a Club 25 programme targeting this age group to commit to regular blood donation and the maintenance of a healthy lifestyle will improve the long-term safety and sufficiency of the country's blood supply $(9,10)$.

Although employment status was not assessed in 2007, the majority of donors in 2000 were employed $(81 \%)$. This has implications for the ideal location and hours of operation of the collection centres and the desirability of increased mobile collection units in order to facilitate the retention of these donors. The continued collaboration between corporate entities and the NBTS may prove beneficial in increasing the awareness and the availability of potential donors.

Although first-time donors predominated in both years, the proportion declined in the 2007 study period. The prevalence of the markers of TTI in first time donors when compared to donors giving one to four times previously did not show a major difference. It is likely that donors who had one to four previous donations did not strictly meet the criteria of regular repeat donors. A crucial challenge in developing countries like Jamaica is the retention of blood donors. This is evidenced by the predominance of first time donors and a dramatic decline in the number of repeat donors as demonstrated in this study. The first step toward blood safety remains the recruitment of voluntary non-remunerated donations from low-risk repeat donors $(1,2)$.

The overall TTI prevalence rates were $6.5 \%$ and $7.4 \%$ for 2000 and 2007, respectively. Volunteers in 2000 were less likely to be seropositive (3.6\%) than replacement donors (6.7\%). The same trend continued in 2007 with $1.2 \%$ seropositivity for volunteer donations and $7.8 \%$ for replacement donations. This is consistent with published reports regarding seropositivity rates in these two groups (11). In develop- ing countries like Jamaica with limited access to technological advances in testing procedures, the safety of the blood supply may be improved by ending the dependence on replacement donors as the main source of blood products. An additional advantage is that once recruited, a volunteer donor is more likely to be retained than a replacement donor (12). Resources need to be specially assigned to this end, in view of the superior long-term benefits.

Autologous donations continue to be underutilized despite doubling over the seven-year period. The superior safety of autologous donations has been well established but the cost benefit ratio needs to be analysed to decide whether this type of donation should have a bigger role in improving the blood supply.

The presence of minor changes over the periods studied may be related to logistic and administrative weaknesses. These include the location, staffing and hours of operation of collection centres as well as the degree to which the care of donors is fostered and the value of the gift is recognized. The cultural factors which impact voluntary donation are deeply ingrained and modification of these will take time. This may be best achieved if education is commenced long before the age at which blood donation is commenced.

\section{REFERENCES}

1. Key KK. Nations meet on securing safe blood supply. AIDS Weekly Plus 1995 Nov 20.

2. Bharucha ZS, Reporter RM, D'mello L. Towards increasing blood safety. Abstract (PC0387) presented at the tenth International Conference on AIDS. Yokohama, Japan; 7-12 Aug 1994.

3. World Health Organization. Global blood safety and availability. Facts and figures from the 2007 Blood Safety Survey. Geneva: World Health Organization; 2009 [updated 2013 Jun; cited 2011 Mar 9]. Available from: http://www.who.int/mediacentre/factsheets/fs279/en/index.html

4. Brady-West DC, Buchner LM. Retrospective audit of blood donation at a hospital-based blood centre - implications for blood product supply and safety. West Indian Med J 2000; 49: 226-8.

5. Masser BM, White KM, Hyde MK, Terry DJ. The psychology of blood donation: current research and future directions. Transfus Med Rev 2008; 2: 215-33.

6. The Center for International Rehabilitation. International disability rights monitor (IDRM) publications. Jamaica - 2004 IDRM country report. 2004 [cited 2011 Mar 9]. Available from: http://www. ideanet.org/content.cfm?id=5B5C74

7. Food and Agriculture Organization. Jamaica: country report on the state of plant genetic resources for food and agriculture. 2008 [cited 2011 Mar 9] Available from: http://www.fao.org/docrep/013/ i1500e/Jamaica.pdf

8. World Health Organization. World Blood Donor Day 14 June 2010. New blood for the world. 2010 [cited 2011 Mar 9]. Available from: http://www.who.int/worldblooddonorday/en/

9. Carolan P. Five-year impact study on Club 25 programmes. Transfusion Today 2010; 83: 6 .

10. Viswanathan C. Are our donors safe? Indian J Pediatr 2001; 68: 69-75.

11. Moor AC, Tom MA. Transfusion-transmitted diseases: risks, prevention and perspectives. Eur J Haematol 1999; 62: 1-18.

12. Mujeeb SA, Kausar A, Khalid M. Seroprevalence of HBV, HCV, HIV infection among college going voluntary blood donors. J Pak Med Assoc 2000; 50: 269-70. 